\title{
BR::ACE
}

Instructions for authors, subscriptions and further details:

http://brac.hipatiapress.com

\section{La Bianyal. Contemporary Art and Heritage Route in La Vall de Bianya}

David Santaeulària ${ }^{1}$

1) Curator of exhibitions and Cultural Manager (Spain)

Date of publication: October $3^{\text {rd }}, 2016$

Edition period: October 2016 - February 2017

To cite this article: Santaeulària, D. (2016). La bianyal. Contemporary art and heritage route in La Vall de Bianya. [Review of the exhibition]. Barcelona, Research, Art, Creation, 4(3), 324-330. doi: 10.17583/ brac.2016.2067

To link this article: http://dx.doi.org/10.17583/brac.2016.2067

\section{PLEASE SCROLL DOWN FOR ARTICLE}

The terms and conditions of use, except where otherwise noted, are related to the Open Journal System and to Creative Commons Attribution License (CCBY). The indication must be expressly stated when necessary. 
BRAC - Barcelona Research Art Creation. Vol. 4 No. 3, October 2016, pp. 324-330

(Received: 27 April 2016; Accepted: 27 July 2016; Published: 3 October 2016)

\section{Reviews (I)}

La Bianyal. Contemporary Art and Heritage Route in La Vall de Bianya

The official literature says that the Bianyal is a cultural route organised by La Vall de Bianya Council and the Binari Association, whose focal point is a series of ephemeral artistic interventions carried out in spaces in La Vall de Bianya with significant heritage interest. Given this point of departure, participants take a tour which offers a chance to spotlight historical, architectural and natural features of much of this town. In short, it is a meeting point between modernity and heritage in a privileged setting designed for all audiences. Indeed, it is all this, but this generic definition does not hint at the product's real virtues. The uniqueness of the Bianyal lies in the sum of elements which are balanced and enhance each other until achieving a particular formula. Let's see what those elements are.

La Vall de Bianya is an extensive township $\left(95 \mathrm{~km}^{2}\right)$ located in the northeast of Catalonia, near the French border, with a little over 1,300 inhabitants scattered around in small settlements. There is no spectacular landmark here, nor anything in particular that characterises the town, but its small valleys make for a cosy, friendly, domestic land where the natural and landscape assets combine with the numerous Romanesque churches and splendid country estates. In each edition of the Bianyal, the organisers design a different route that includes new points of interest. After seeing these places and learning about their purpose and their history, they are where the artists carry out their interventions. Sometimes they are site-specific works, while other times they are simply pieces whose subject matter or formalisation are a good fit for the

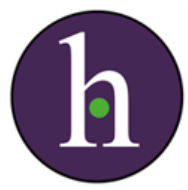


chosen venue. Only in cases where the space is more neutral and has fewer connotations do we allow more generic works to be installed. The capacity to adapt to the space or the match between the works and the venue where they are exhibited are two of the criteria governing the choice of artists, in addition to a broad span of generations and diversity and representativeness in the way the artists approach contemporary creation. Two editions of the Bianyal have been held to date, featuring works by artists such as Job Ramos, Kenneth Russo, Jordi Mitjà, Quim Domene, Pedro G. Romero, Lúa Coderch and Roger Serrat-Calvó. The Bianyal routes are taken with groups limited to around 50 people per session accompanied by a guide who, while trying to avoid overly academic explanations, provides clues to understanding the importance of the churches in the organisation of rural life, or what the more traditional day-today life was like, or the evolution of the landscape, etc. The participants are particularly varied (from cultural managers and artists to townspeople or people from neighbouring towns), which requires the explanations to be adjusted and the contents made accessible to viewers who may not be connoisseurs.

All of this is joined by more random ingredients, such as a reception offered featuring local products, or the mini-train which connects the different venues at a slow pace that helps viewers enjoy the landscape, or intangibles like the autumn atmosphere and colours. As you can see, there is nothing particularly original in itself; instead, the sum and balance of all of the elements is what everyone - viewers and artists alike - believe to be the Bianyal's main appeal. It would hardly be able to work if any of these aspects were missing or anyone was overly foregrounded. The Bianyal is not meant to be a pretext to land the most prestigious or exclusive list of artists (it is not engaged in a hypothetical competition with other biennales). It is not either a tourist promotion tool and it would not obviously boast the same quality if it were not a guided tour or if visitors did not have the chance to listen to the artists' explanations. One sound indicator of the event's health is the speed with which the registrations for each visit fill up and the number of artists who offer to participate in future editions.

David Santaeulària Curator of exhibitions and Cultural Manager dsantaeularia@gmail.com 


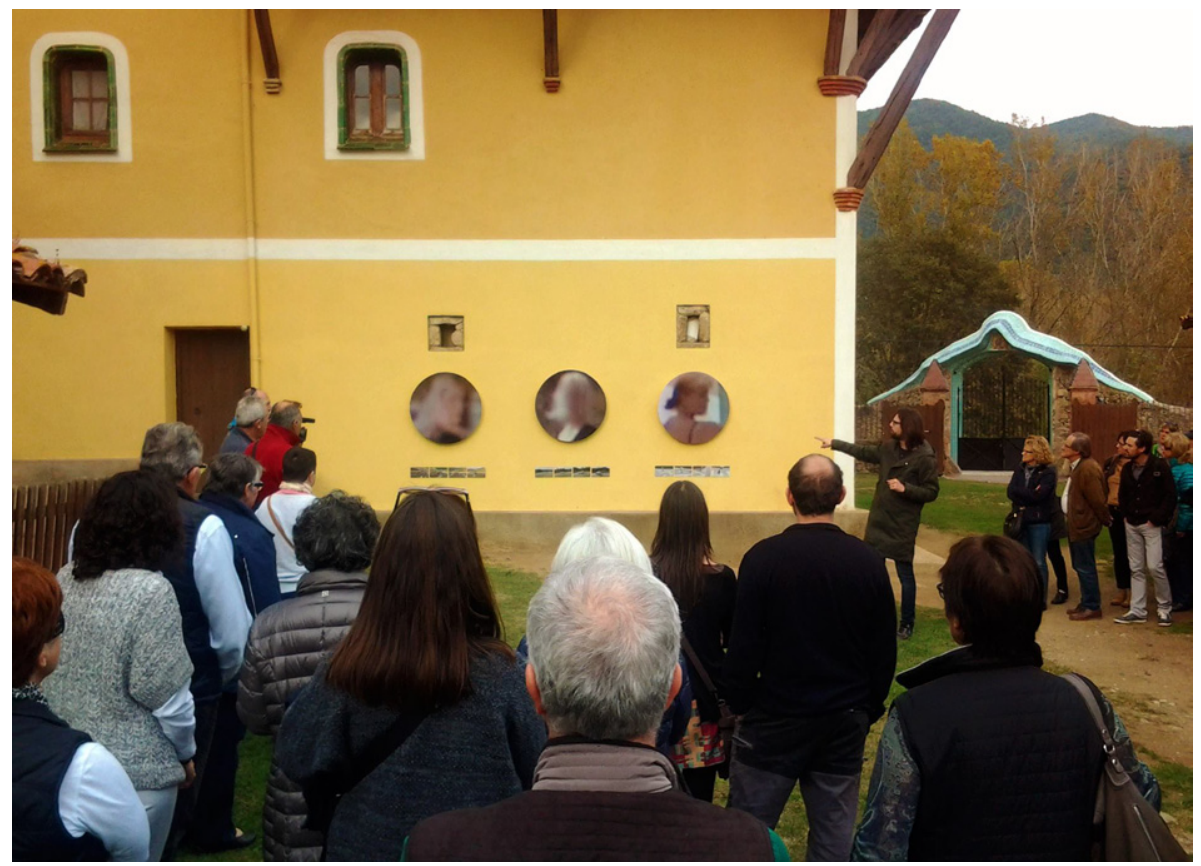

Figure 1. Roger Serrat-Calvó explaining his work $R G B$ portraits (La Coromina farmhouse, La Vall de Bianya). Photo: David Darné (CC BY). 


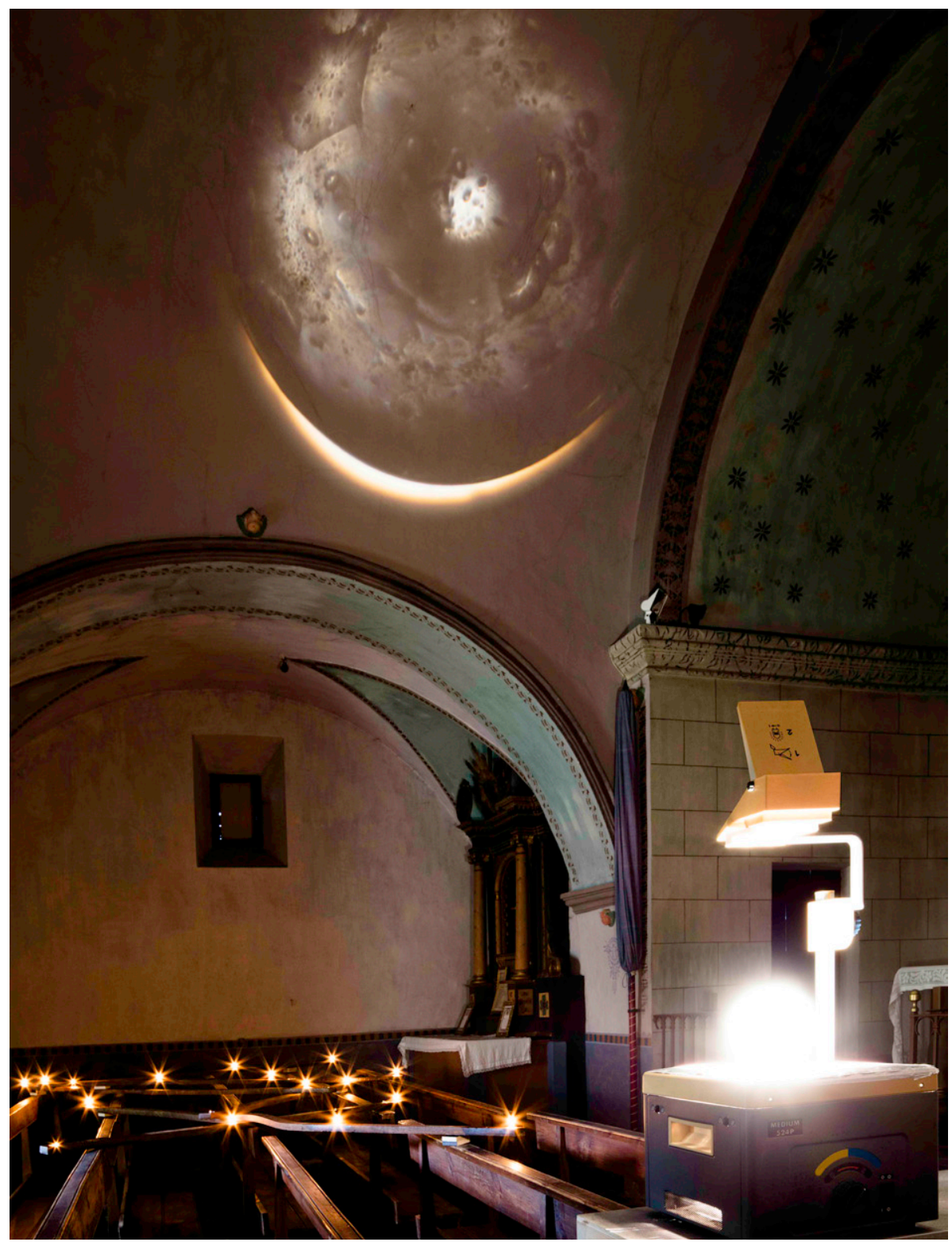

Figure 2. Òcul i llumenera, installation by Jordi Mitjà (church of Sant Martí de Solamal, La Vall de Bianya). Photo: Roger Serrat-Calvó (CC BY). 


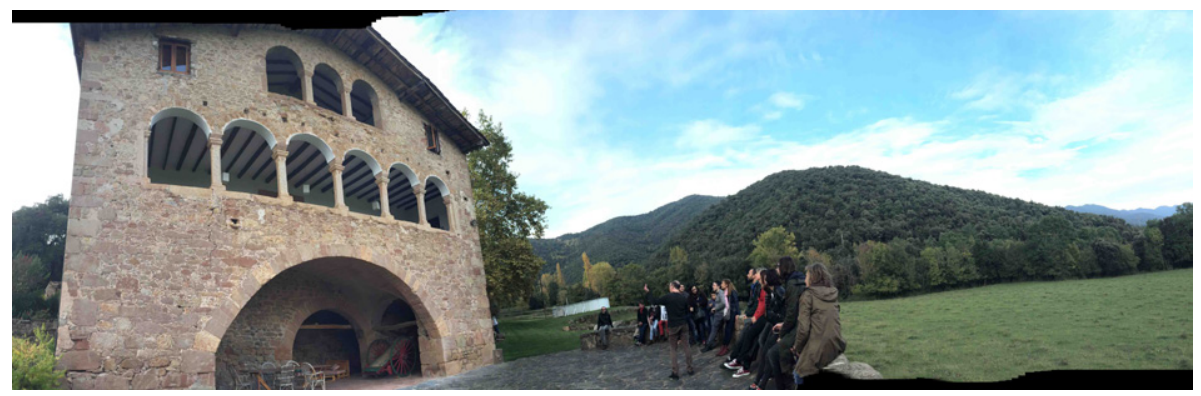

Figure 3. El Callís farmhouse (La Vall de Bianya). Photo: David Darné (CC BY).

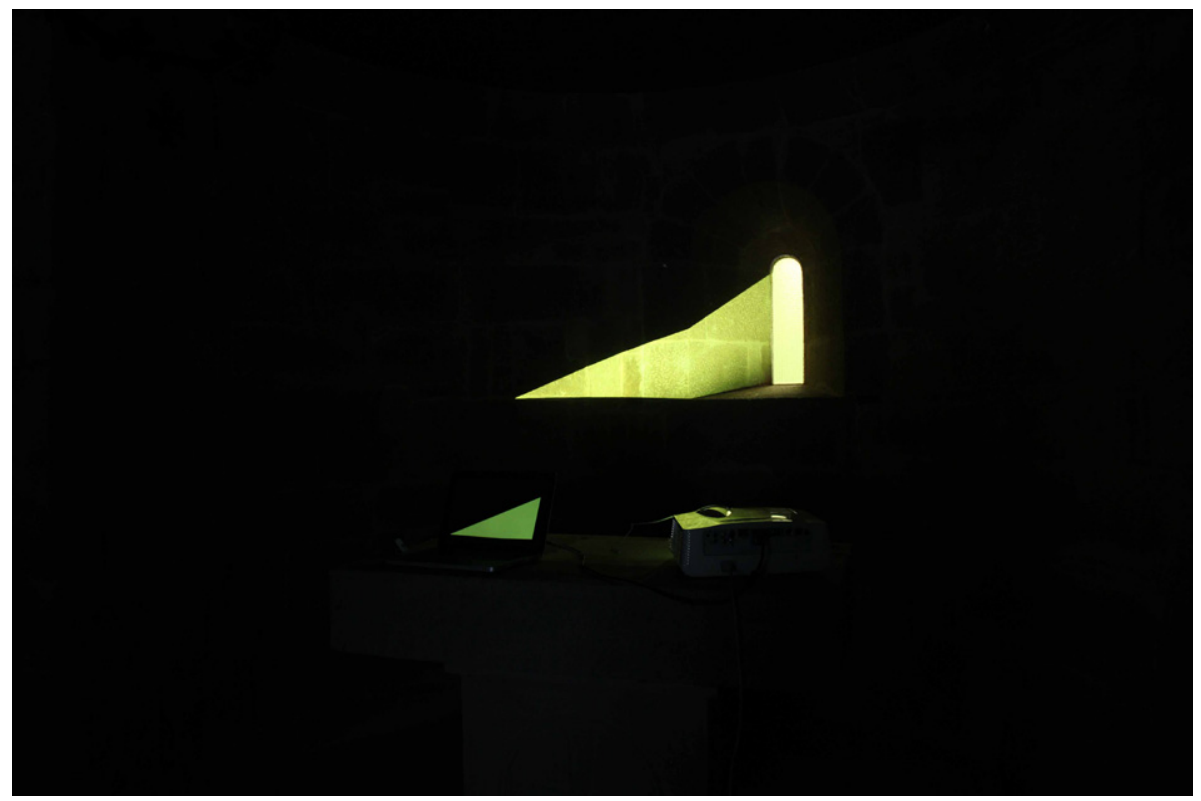

Figure 4. Installation by Job Ramos (Sant Andreu de Sucarrats, La Vall de Bianya). Photo: Roger Serrat-Calvó (CC BY). 


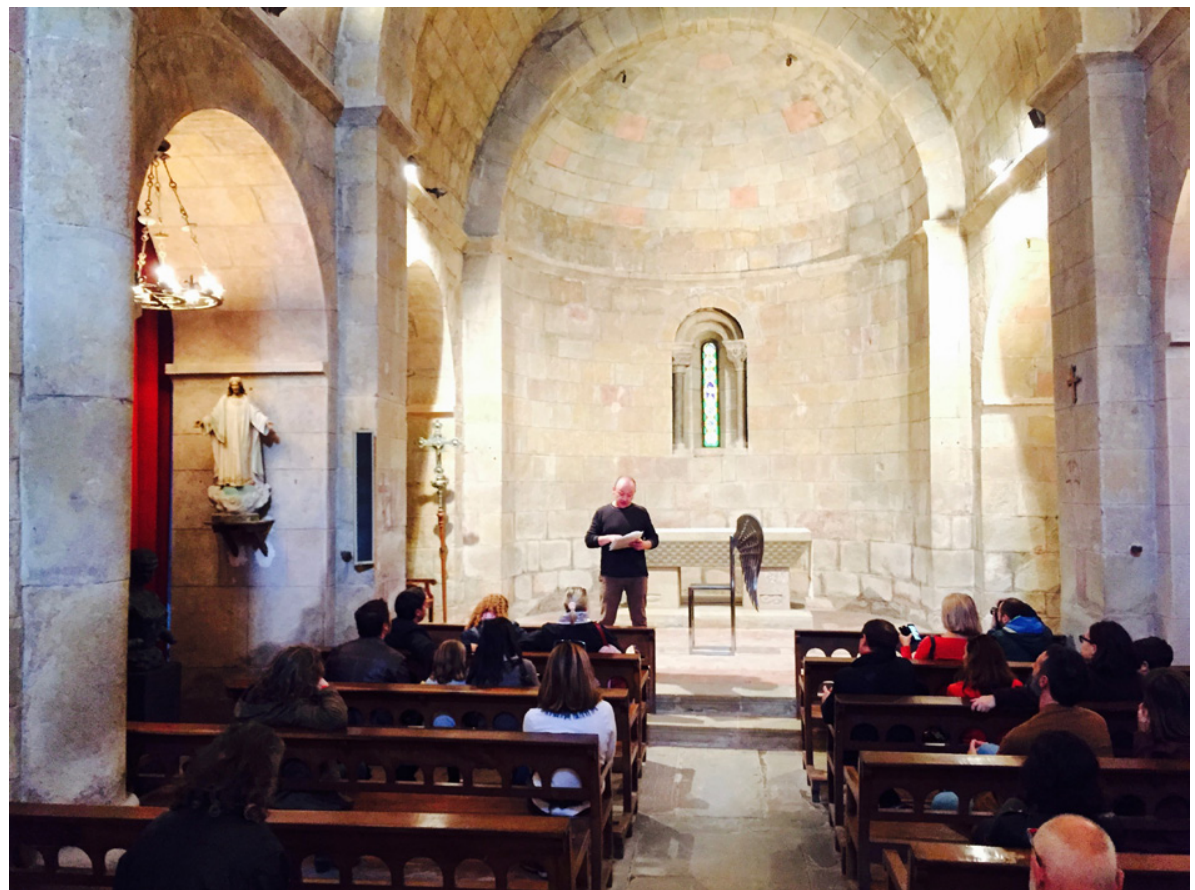

Figure 5. Church of Sant Salvador de Bianya (La Vall de Bianya). Photo: Roger Serrat-Calvó (CC BY).

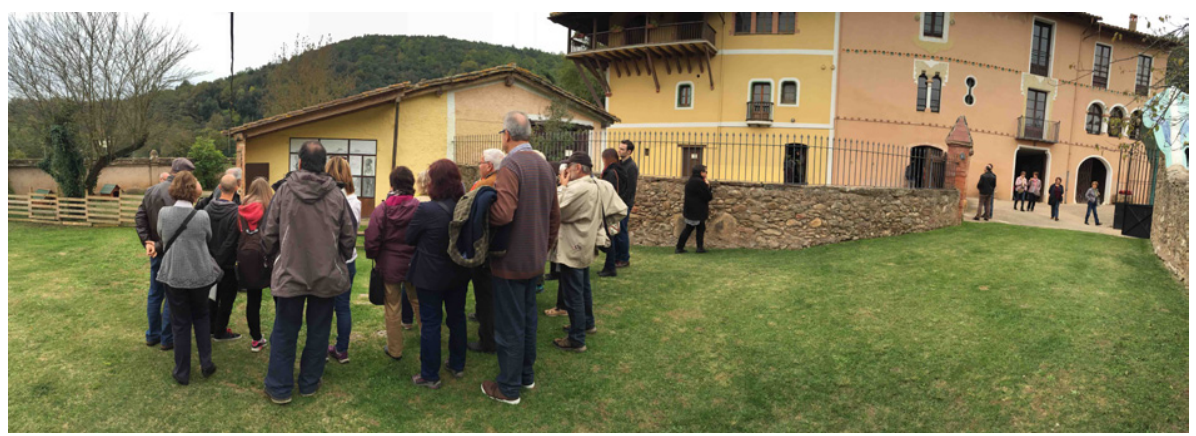

Figure 6. Mim Juncà explaining his work (La Coromina farmhouse, La Vall de Bianya). Photo: David Darné (CC BY). 
330 David Santaeulària - La Bianyal

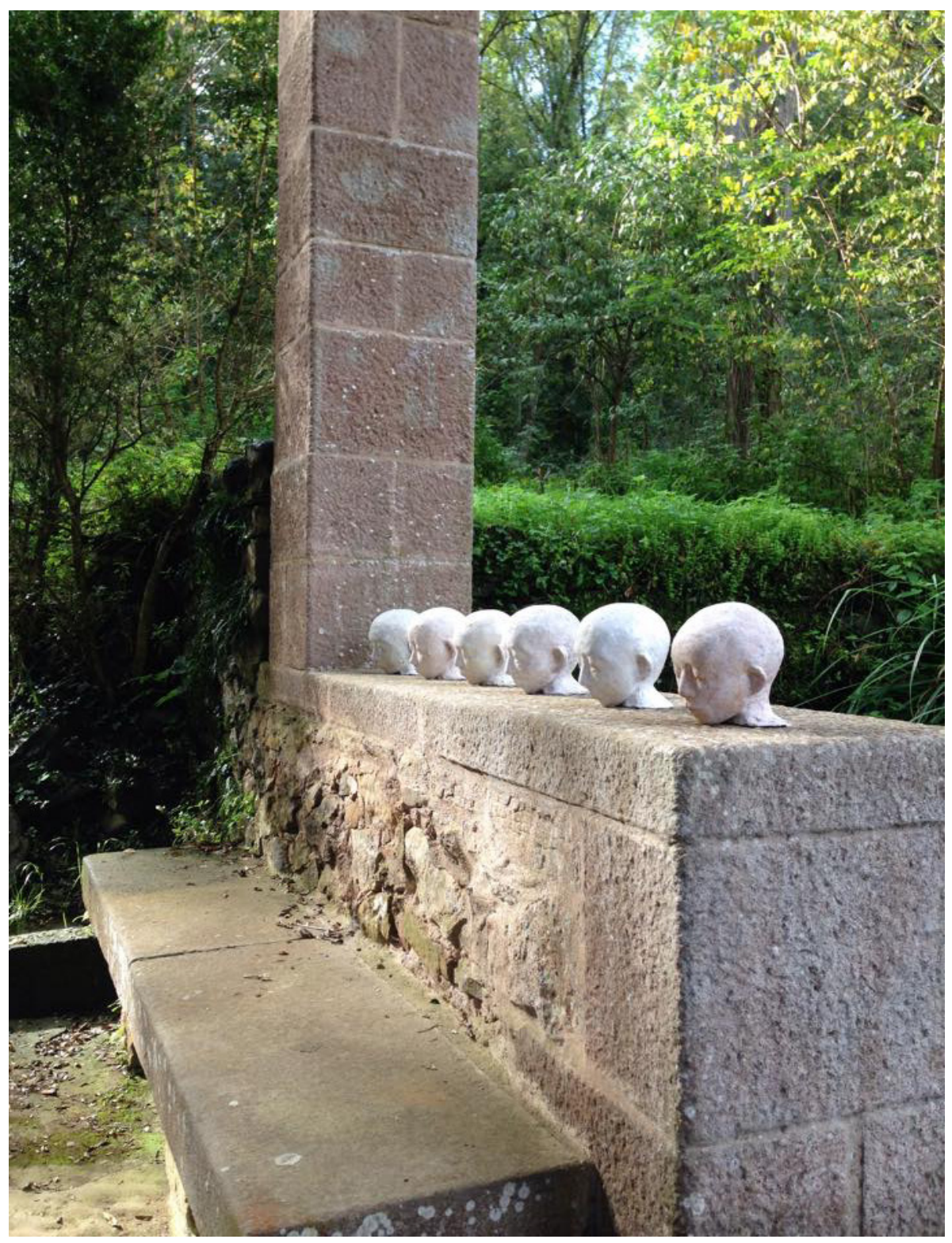

Figure 7. Installation by Anna Manel·la (Sant Andreu de Sucarrats, La Vall de Bianya). Photo: Roger Serrat-Calvó (CC BY). 